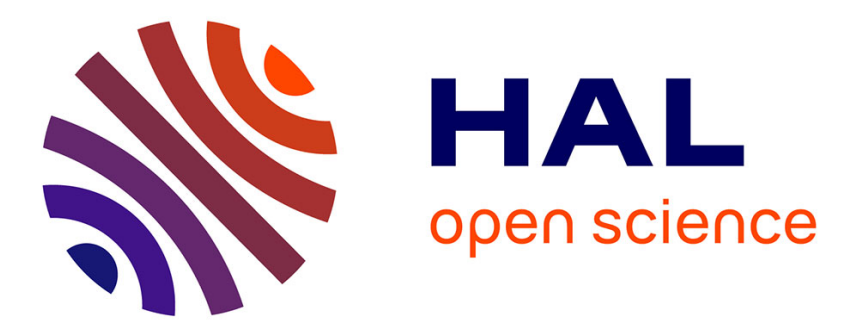

\title{
Adaptive measures for mountain Mediterranean forest ecosystem services under climate and land cover change in the Mont-Ventoux natural Regional Park, France
} Laetitia Tufféry, Hendrik Davi, Noelia López-García, Eric Rigolot, Florence Jean, Anne Stenger, Francois Lefèvre

\section{To cite this version:}

Laetitia Tufféry, Hendrik Davi, Noelia López-García, Eric Rigolot, Florence Jean, et al.. Adaptive measures for mountain Mediterranean forest ecosystem services under climate and land cover change in the Mont-Ventoux natural Regional Park, France. Regional Environmental Change, 2021, 21 (1), pp.22. 10.1007/s10113-020-01732-4 . hal-03050650

\section{HAL Id: hal-03050650 \\ https://hal.inrae.fr/hal-03050650}

Submitted on 10 Dec 2020

HAL is a multi-disciplinary open access archive for the deposit and dissemination of scientific research documents, whether they are published or not. The documents may come from teaching and research institutions in France or abroad, or from public or private research centers.
L'archive ouverte pluridisciplinaire HAL, est destinée au dépôt et à la diffusion de documents scientifiques de niveau recherche, publiés ou non, émanant des établissements d'enseignement et de recherche français ou étrangers, des laboratoires publics ou privés. 


\title{
Adaptive measures for Mediterranean mountain forest ecosystem services under climate and land cover change in the Mont-Ventoux Natural Regional Park, France
}

Tuffery L.* , Davi H., López-García N., Rigolot E., Jean F., Stenger A., Lefèvre F.

Corresponding author: Laetitia Tuffery, CEE-M, INRAE, Montpellier SupAgro, CNRS, Univ. Montpellier, Montpellier, France. Email: Laetitia.tuffery@inrae.fr, Tel: +33680675587

Davi Hendrik, UR629, Écologie des Forêts Méditerranéennes, INRAE, Avignon, France. Email: Hendrik.davi@inrae.fr

López-García Noelia, Southern Swedish Forest Research Centre, Swedish, University of Agricultural Sciences, Box 49, 23053, Alnarp, Sweden. Email: noelia.lopez.garcia@slu.se

Eric Rigolot, Écologie des Forêts Méditerranéennes, INRAE, Avignon, France. Email: eric.rigolot@inrae.fr

Florence Jean, Écologie des Forêts Méditerranéennes, INRAE, Avignon, France. Email: florence.jean@inrae.fr

Anne Stenger, Université de Strasbourg, INRAE, BETA, 54000, Nancy, France. Email: anne.stengerletheux@inrae.fr

François Lefèvre, UR629, Écologie des Forêts Méditerranéennes, INRAE, Avignon, France. Email: François.lefevre.2@inrae.fr

\begin{abstract}
Climate change (CC) and land use and land cover change (LULCC) threaten Mediterranean forests and the ecosystem services (ES) they provide. In complex socio-ecological systems and under high uncertainties, the resilience of ES has become the target objective for adaptive management strategies driven by decision makers and local stakeholders. This work develops an integrative and territorial approach to combining biophysical modeling and local managers' assessments to elaborate scenarios of LULCC in response to climate and socioeconomic changes. It also evaluates the impacts of forest ecosystem changes on coupled ES for different time horizons for a case study of the mountain Mediterranean forests of Mont-Ventoux Natural Regional Park. The results demonstrate first that the future ES provisions predicted by biophysical modeling in this area are less affected by CC than expected by local managers. Furthermore, LULCC increases the changes in ES provision and accentuates the difference between climate scenarios. These results originate from a combination of two effects: (1) pessimistic predictions by local managers and, as a consequence and (2) anticipatory actions that tend to reinforce or even accelerate the expected changes in the mountain Mediterranean forest area.
\end{abstract}

Key words: mountain Mediterranean forests, ecosystem services, climate change, adaptive scenarios, socio-ecological approach

Length of the manuscript: 7715 words (including 6 tables and figures) 


\section{Introduction}

Climate change (CC) and land use land cover change (LULCC) have become the two biggest threats to Mediterranean forests, profoundly altering the future of forest ecosystem services (ES) (Lamarque et al., 2014; Choe and Thornes, 2017). Awareness of CC and uncertainty modifies forest management and political decisions from sustainable management to the adaptive strategy perspective (von Detten, 2011; Hoogstra-Klein \& Burger 2013; Lidskog \& Löfmarck 2015, 2016). In the adaptive management perspective, three main issues must be considered: (1) the forest ecosystems will change as driven by climate and human decisions, (2) the demand on ES will change as driven by societal evolution and (3) the changes in forest ecosystems will have multiple impacts on multiple ES. The exploration of future delivery of ES in socioecological systems (SES) must integrate complex interrelations and feedback among economic activities (e.g., forestry), land use, local environmental conditions and ecological dynamics.

Currently considered as an interesting approach by the scientific and decision maker communities, the future delivery of ES has been increasingly studied through exploratory scenarios (Harmáčková and Vačkář, 2018; Berg et al., 2016; van Vuuren et al., 2011). Scenario construction relies on qualitative narratives (for example, the evolution of local management policies or social preferences) and their transcription into quantitative changes (input variations such as temperature, quality of soil, demand for renewable energy, etc.) (Martinez-Harms et al., 2017). Mediterranean forests provide good case studies of multifunctional SES (Croitoru, 2007; Masiero et al., 2016), as they are biologically and ecologically diverse, rapidly changing, and heterogeneous in ownership and management systems (FAO, 2014; Martinez de Araño et al, 2018).

In the case of Mediterranean forests, the expected impacts of global changes on future ecosystem functioning and sustainability have already been listed (FAO, 2014). The literature discusses several factors of changes (CC, LULCC, and ecosystem management policies) using different methods (statistical/correlation analysis and process-based modeling) to evaluate their impacts on ES production and value. A recent literature review on models and scenarios used to assess the future of the Mediterranean forest ES (Morán Ordóñez et al., 2018) showed that only a few studies used processbased models while the majority of studies evaluated only one driver of change, i.e., CC.

In particular, integrated prospective analyses of future ES delivery can be improved by a combined approach addressing three major challenges:

(i) Implementing biophysical modeling to better estimate the balanced effects of $\mathrm{CC}$ (e.g., longer growing season or increasing drought) and $\mathrm{CO}_{2}$ fertilization on ecosystem functions;

(ii) Combining biophysical models and managers' expert assessments to elaborate scenarios of LULCC in response to climate and socioeconomic changes; and

(iii) Combining biophysical and economic approaches to evaluate the impacts of forest ecosystem changes on multiple-ES delivery at a territorial scale for different temporal horizons.

Such integrated assessment of ES is still largely missing due to integration complexity, implying different ecosystems, ES, values, temporal and spatial scales, stakeholders and disciplines (Tardieu, 2017).

The biophysical evaluation of ES is commonly based on empirical linear models (Lamarque et al., 2014, Martinez-Harms et al., 2017, Schirpke et al., 2017) that estimate the determinants of ES, including ecological processes and human practices. These relationships are first documented in different climate or land use contexts, accounting for current spatial and past temporal variations, then applied in future conditions. These empirical models assume a stable relationship between eco-physiological ecosystem characteristics and ES provision. As these effects are empirically estimated using past and present 
observations of the relationships between climate and ES, they do not account for complex and dynamic changes in forest functioning in the future climate context. Thus, they are considered unable to incorporate the effects of changing environmental conditions on tree and stand growth (Fontes et al., 2010). By contrast, process-based models have thus been considered particularly convenient for the investigation of forest dynamics under new environmental conditions (Fontes et al., 2010; OddouMuratorio et al., 2020).

Only few publications consider a combined approach for the study of global change impact on the future provision of ecosystem services at the landscape scale (Kubiszewski et al., 2017; Small et al., 2017; Costanza et al., 2011) or at a local scale (Ding et al., 2016; Bottalico et al., 2016; Masiero et al., 2016). However, integrated study of ES considering both supply side (ES provided by ecosystems according to ecological functions) and demand side (beneficiaries of ES) in spatially explicit terms is currently recognized as a powerful tool to help environmental and management planning decisions (Tallis and Polasky, 2009; De Groot et al., 2010; Garcia-Nieto et al., 2013). The economic valuation of CC and LULCC impacts on the production of ES is an important step to solving potential conflicts between beneficiaries or establishing guidelines for sustainable forest management considering the potential trade-offs or synergies between ES (Kubiszewski et al., 2017).

In this work, we studied Mont-Ventoux Natural Regional Park. We developed a methodology to explore the effects of different scenarios of forest policies and CC on changes in carbon sequestration (regulation and maintenance ES) and timber production (provisioning ES) in spatially sensitive and dynamic ways, combining biophysical and economic values. We designed different forest management options under climate scenarios to estimate the resilience of Mediterranean forest ES according to their ecological and economic trajectories in two time horizons, 2050 and 2100. We first used a stakeholderbased analysis to estimate the evolution of ES production according to the LULCC. This first step was based on the InVEST model and its stakeholder matrices tool (i.e., InVEST models; Kareiva et al, 2011). Then, we used a biophysical model to assess the future state and functions of different forest types (i.e., climate impact on ecosystem functions) using simulations on nine forest types at five altitude levels for three soil water depths, two canopy openness values and two aspects (i.e., CASTANEA model; Dufrêne et al., 2005; Davi and Cailleret, 2017). This combined model-based approach (i.e., LULC modeling and physiological assessment of forest functioning) allowed us to jointly explore the future effect of LULC and CC on forest ecosystems. Moreover, this approach combined a spatially explicit ES analysis and an economic valuation.

We used an integrated approach to investigate how climate and LULCC factors impact the different ES and to analyze whether the changes in ES are due to climate scenarios or LULCC scenarios (including adaptation) and whether some LULCC scenarios can offset the effect of climate.

\section{Methodology}

Figure 1 presents the four steps of our methodology.

2.1 Land cover map of the studied area

The case study is on Mont-Ventoux Natural Regional Park in France, a Mediterranean forest socioecological system. Located in the southern part of France (the Provence region), the current perimeter of the Mont-Ventoux park covers a total area of $987 \mathrm{~km}^{2}$. Mont Ventoux peaks at 1,912 $\mathrm{m}$ a.s.l. The territory is occupied by $57.7 \%$ forest and semi-natural environments and hosts a great diversity of 
natural habitats linked to a unique bioclimatic and geomorphological context (Barbero and Quezel, 1976). Because of its altitudinal gradient and its intermediate geographical location between the Alpine and Mediterranean regions, the Ventoux area presents a high diversity of environments.

We characterized our study territory according to a typology compatible with the ecological and land cover models, i.e., a mono-specific and spatially representative typology. We used two main geographic databases: the French forest database by the National Geographic Institute in 2012 (BDForêt ${ }^{\circledR}$ ) and the Corine Land Cover database in 2012. Finally, we obtained 37 types of land covers comprising (see Fig. 2): nine locally predominant tree species (Quercus pubescens, Quercus ilex, Fagus sylvativa, Pinus nigra, Pinus sylvestris, Pinus halepensis, Pinus unicinata, Abies alba, Cedrus atlantica) and five bioclimatic stages (plain, Mediterranean, supra-Mediterranean, lower mountain, and higher mountain), five groups of companion species, moors, fire areas, and three aggregated LULCs (artificial areas, agricultural areas and various vegetation). This typology allowed us to work on mono-specific process-based and fine-scale (i.e., non-aggregated) LULC models. The spatial resolution was $25 \mathrm{~m} \times 25$ $\mathrm{m}$ grid (i.e., 1 ha $=16$ pixels).

\subsection{Exploratory scenario narratives}

Our exploratory scenarios are based on two main drivers, CC and forest policy, defined over two time horizons: short term (2050) and long term (2100).

\subsubsection{Establishment of a local stakeholder panel}

The scenario construction started with the identification of the effects of the drivers of change on local forest ecosystems, which we achieved in close relationship with local stakeholders and managers (McKenzie et al., 2012). To do so, the first step was to identify a panel of stakeholders and managers to define and improve our scenarios and collect their knowledge on local forest resources and management. As recommended by the NatCap team in their InVEST guide and in the existing literature on this topic (Berg et al., 2016; Tallis et al., 2013), our stakeholder panel participated in four iterative meetings: scenario narrative construction (e.g., local forest policy orientation, biodiversity protection, and timber market evolution), data and inputs for the assessment (e.g., forestry planning by species and stage, harvest mass, cost of production and prices), future LULC and the transition matrix construction, and reviewing and improving the ES outputs. The stakeholder panel is presented in Appendix A.

\subsubsection{Current local climate and downscaled climate change scenarios}

We used the Safran meteorological analysis system (Durand et al., 1999), which provides past meteorological daily input data on a regular grid $(8 \times 8 \mathrm{~km})$. Then, we used two points of the grid located in the Ventoux, one at the north and the other at the south, to calibrate the climatic clines used in the simulations. To account for altitudinal effects on climate, local measurements were taken at ten forest sites targeted in the study from local weather stations (2007-2015). The minimum, maximum, and average temperatures, rainfall and relative humidity were recorded with a Prosensor HOBO Pro (RH/Temp; Onset Computer Corporation, Bourne, MA 02532, USA). Regression coefficients were estimated between these local stations and the Safran climate data at the two grid points. These 
regression coefficients were then used to generate daily climate data from 1959 to 2015 based on the long-term SAFRAN outputs using the equations described by Oddou-Muratorio and Davi (2014).

For the future climate, we used the Hadley Centre Global Environmental Model version 2 (HadGEM2) and the Coupled CNRM - CM/AOGCMs - atmosphere-ocean general circulation models. From all existing climate models, CNRM - CM5 is the coldest model that can also predict an increase in precipitation, and HadGEM2 - ES is the warmest model that can predict a decrease in rainfall (McSweeney et al., 2015). We considered two CC scenarios: RCP 4.5 (Representative Concentration Pathway ${ }^{1}$ ) and RCP 8.5. RCP 4.5 is the more optimistic scenario, and RCP 8.5 is the more pessimistic scenario. RCP 8.5 is estimated using the Model for Energy Supply Strategy Alternatives and their General Environmental Impact (Moss et al., 2010) predicting a rising up to 1,370 ppm CO CO $^{-e q}$ in 2100. These climate predictions were downscaled at the two studied points of the Safran grid using the 19602015 period as a reference using the R-package 'meteoland' (De Cáceres et al., 2015). Both scenarios follow the same trend until 2050, but they strongly diverge between 2050 and 2100 (see Appendix B).

\subsubsection{Global forest policy scenarios and local forest management options}

The global forest policy scenarios are based on the plausible futures of the European forestry sector published by the UNECE FAO section (European Forest Sector Outlook Study II - EFSOS II; FAO, 2011). Among the four EFSOS scenarios, we selected the three most relevant forest policies in our study area: business as usual (BAU), promotion of wood energy (WE) and biomass and carbon sequestration maximization (BIO). The first corresponds to the evolution of land cover (i.e., LULCC) related to "as usual" forest management, without adaptation, whereas the latter two, BIO and WE, correspond to forest management policies for adaptation to global changes.

We adapted the EFSOS scenarios to our case study by translating them into a short narrative description that was then validated by the stakeholders. A brief description of the scenarios used in this work is in Appendix C (Table C1).

The three forest policy scenarios and their related forest management options affect forest management regimes (e.g., thinning, harvest period). The forestry planning is accurately described in Table 1.

These scenarios resulted in 12 combinations ( 2 time horizons $\times 2 \mathrm{RCP} \times 3$ forest policies), producing our 12 scenarios (see Appendix C, Fig.2).

\subsection{Models}

As presented in Figure 1, our two global change drivers, climate change and forest policy, were then used as inputs for the LULC and process-based models. All data sources used in these methods are presented in Appendix D.

\subsubsection{Land cover change model}

The three forest policy scenarios and their related forest management options affect forest management regimes (e.g., thinning, harvest period). The forestry planning is accurately described in Table 1.

\footnotetext{
${ }^{1}$ The modeled climate scenario data follow the Representative Concentration Pathways (RCP).
} 
For the construction of different potential futures, we used InVEST, which allows incorporation of complex scenarios combining climate, policy factors and local stakeholder expertise (Kareiva et al., 2011; Tallis et al., 2013). Forest management options under different climate change contexts are translated first into forest planning options, then into transition matrices and finally into maps. Stakeholder and manager interviews provided local information on tree species choices according to the potential mortality or adaptation of each species in a global change context. The methodology to express the transition probabilities from the corpus of information provided by the panel of stakeholders follows the recommendations of the InVEST guide. The transition probabilities depend on the percentage of change from one land cover type to another and the two surface areas of the original and final land covers. Given our 37 land cover types and 12 scenarios, the required information represents a complex overview. Stakeholders provided the rate of area change in each land cover for each scenario and at the two time horizons, given in matrix $A$, as follows:

\begin{tabular}{|c|ccc|c|}
\hline From $F_{i}$ & $F_{1}{ }^{\text {To } F^{\prime}{ }_{j}}$ & $\ldots$ & $F^{\prime}{ }_{37}$ & $\begin{array}{c}\text { Current surface area } \\
S_{i}\end{array}$ \\
\hline$F_{1}$ & $P_{1,1}$ & $\ldots$ & $P_{1,37}$ & $S_{1}$ \\
$\vdots$ & $\vdots$ & $\ddots$ & $\vdots$ & $\vdots$ \\
$F_{37}$ & $P_{37,1}$ & $\ldots$ & $P_{37,37}$ & $S_{37}$ \\
\hline $\begin{array}{c}\text { Future surface area } \\
S^{\prime}{ }_{j}\end{array}$ & $S^{\prime}$ & $\ldots$ & $S^{\prime}{ }_{37}$ & \\
\hline $\begin{array}{c}\Delta \text { Surface area } \\
O_{j}\end{array}$ & $O_{1}$ & $\ldots$ & $O_{37}$ & \\
\hline
\end{tabular}

with $F_{i, j}$ as the LULC categories, from type $i=1, \ldots, 37$ to type $j=1, \ldots, 37$. $P_{i, j}$ is the proportion, between 0 and 1 , of the total surface of land cover type $i$ that becomes a land cover type $j$. The current surface related to each LULC type is $S_{i}$; the future surface, $S_{j}^{\prime}$, based on probabilities in matrix $\mathrm{A}$, is computed as presented by equation (1); and $O_{j}$ is the difference between $S_{i}$ and $S_{j}^{\prime}$ :

$$
S_{j}^{\prime}=\sum_{j=1}^{37} P_{i, j} S_{i}
$$

We finally obtained 12 future land cover maps (one per scenario).

\subsubsection{Process-based model}

CASTANEA is an eco-physiological process-based model used to predict water and carbon fluxes in forest stands (Dufrêne et al., 2005). The canopy is assumed to be horizontally homogeneous and is vertically subdivided into a variable number of layers, each with the same amount of leaf area. One averaged tree is assumed to be representative of the whole stand; therefore, each tree behaves as a dominant tree. In CASTANEA, the tree structure is assumed to be a combination of five different functional parts: stems, branches, leaves, coarse and fine roots (Davi et al., 2005). In addition, a carbohydrate storage section is included. The main simulated output variables are canopy 
photosynthesis, maintenance and growth respiration, tree carbon allocation, soil heterotrophic respiration, tree transpiration, and ecosystem evapotranspiration (Davi et al., 2005).

Species-specific parameters were defined using a literature review, remote sensing and forest inventory data (see Appendix F). The model was first evaluated at four FLUXNET sites, where some of the studied species are present, using growth data on all of the studied species (Davi et al., 2005; Davi et al., 2006; Guillemot et al., 2017; Lopez-Garcia, 2018). Then, the CASTANEA model was used to simulate the water and carbon fluxes across an elevation gradient for different types of stands (open vs. closed, three types of soil, and soil water content) under past and future climate conditions (two contrasted climate models, HADGEM2 and CNRM - CM/AOGCMs and two RCPs, 4.5 and 8.5) with or without silviculture (Appendix B).

Mortality is estimated in the model by accounting for both the mortality induced by hydraulic cavitation and the mortality related to carbon starvation (Adams et al., 2017). Adult mortality is due to either carbon starvation or hydraulic failure (Davi and Cailleret, 2017). We assumed that conifers die when the percentage of conductance loss is greater than 50\% (Brodribb and Cochard, 2009) and that angiosperms die when the percentage of conductance loss is greater than $88 \%$ (Urli et al., 2013). We then estimated the average concentration of non-structural carbohydrates ([NSC] threshold) per species below which trees die from past mortality data recorded in the IGN data. For Holm oak, this method generated an excessively high value for [NSC $]_{\text {threshold; }}$ we then used the maximum value obtained for the other species.

\subsection{Ecosystem services assessment}

We studied two categories of ES, provisioning for timber production and regulating for carbon sequestration, at every time horizon and for all scenarios. To respect the specificity of each ES and the forest multifunctionality outputs, we selected adapted methods for the economic valuation. Thus, we used the price in euros in the French market for the timber production service, and we used a socioeconomic value, i.e., the social cost of carbon (SCC), for the carbon sequestration. In these two cases, the demand is commonly equal to the flow of ES: the biophysical amount of ES is directly converted into monetary units through market prices and costs. These methods are part of the market valuation methods (versus nonmarket valuation, for example, revealed and stated preference techniques), allowing for a better comparison and joint analysis of our pair of ES.

\subsubsection{Carbon sequestration}

At every time horizon, for every scenario and for each forest land cover type $(i=1, \ldots, 35)$, carbon sequestration, Stock ${ }_{i}$, was assessed yearly using the CASTANEA model $\left(\mathrm{t}_{\mathrm{c}} \cdot \mathrm{ha}^{-1}\right.$.year $\left.{ }^{-1}\right)$ using the following equation:

$$
\text { Stock }_{i}=G P P_{i}-R a_{i}-R h_{i}
$$

where $G P P_{i}$ is the gross primary production; $R a_{i}$ the sum of all autotrophic respiration of coarse and fine roots, branches, stem and leaves; and $R h_{i}$ is the heterotrophic respiration of soil. 
The economic valuation is based on the social cost of carbon (SCC). It corresponds to the reduction of future damage, i.e., avoided damage, caused directly or indirectly by the emission of an additional ton of $\mathrm{CO}_{2}$, by reducing theses emissions. We computed the economic value of carbon sequestration as follows:

$$
\begin{aligned}
& \text { Stock_NPV } V_{i}=\frac{S C C \times \text { Stock }_{i}}{(1+r)^{t}} \\
& \text { Stock_TNPV } V_{i}=S t o c k_{-} N P V_{i} \times S_{i}
\end{aligned}
$$

where Stock_NPV $V_{i}$ and $S t o c k_{-} T N P V_{i}$ are the net present value (NPV) and the total net present value (TPNV) of carbon sequestration in euros, respectively, SCC is the current and fixed social cost of carbon, $C C_{i}$ is the carbon sequestration (equation (2)), $\mathrm{t}$ is the total number of years during the studied period (to obtain the mean annual sequestration), and $r$ is the discount rate. The surface of each forest land cover type $i$ is given by $S_{i}$ (or $S_{i}^{\prime}$ for the future).

The literature has proposed a large range of SCC. Then, as recommended in the literature on this topic (Bottalico et al., 2016), we simplified the analysis and selected only two values (expressed in $€_{2017}$ ), $44 € / \mathrm{tCO} 2$ in 2017 and $57 €_{2017} / \mathrm{tCO} 2$ in 2050 (Watkiss, 2006), and we assumed that those values remain constant between 2050 and 2100 .

\subsubsection{Timber production}

Timber production depends on two main pieces of information, the wood volume in $\mathrm{m}^{3}$.ha ${ }^{-1}$ and the forest planning (thinning, \% of timber harvested, harvest frequency), which vary across time horizons, climate scenarios and policy scenarios.

In CASTANEA the wood volume per ha, $V h a_{i}$ for forest land cover type $i(i=1, \ldots, 35)$, is estimated yearly using the following equation:

$$
V h a_{i}=\frac{B_{\text {stem }_{i}}}{\rho_{\text {wood }_{i} \times t c_{i}}}
$$

where $B_{\text {stem }_{i}}$ is the stem biomass per ha, $\rho_{\text {wood }_{i}}$ is the wood density, and $t c$ is the carbon content of wood (the stem biomass in the model is in $\mathrm{gC} / \mathrm{m}^{2}$ of soil). We did not include new recruitment in our simulated stands.

Then, from the forest planning, we obtained the mass of wood harvested $\left(\mathrm{m}^{3} / \mathrm{ha}\right)$, ThinnedVha $a_{i}$, as follows:

$$
\text { ThinnedVha } a_{i}=V h a_{i} \times \operatorname{harv}_{\text {rate }}
$$

where harv $_{\text {rate }}$ is the percentage of wood harvested for each period studied (see Table 1).

The model used for the timber production net present value, $N P V_{i}$, and the total net present value, $T N P V_{i}$, in euros is the following:

$$
\begin{aligned}
& \text { ThinnedVha_NPV } V_{i}=\frac{\text { ThinnedVha }_{i} \times\left(\text { Price }_{i}-\text { Harv }_{\text {cost }_{i}}\right)-\text { Maint }_{\text {cost }}}{(1+r)^{t}} \\
& \text { ThinnedVha_TNPV } V_{i}=\text { ThinnedVha_NPV } V_{i} \times S_{i}
\end{aligned}
$$

This model includes the mass of wood harvested $\left(\mathrm{m}^{3} / \mathrm{ha}\right)$, ThinnedVha $a_{i}$; the cost of wood harvesting $\left(€ / \mathrm{m}^{3} / \mathrm{ha}\right), \operatorname{Harv}_{\text {cost }_{i}}$; and the cost of maintenance of each plot ( $€ /$ ha), Maint cost $_{i}$. We then computed 
the TNPV, weighing the NPV by the total surface area (in ha). For the economic data, we used the marketplace value of the wood harvested from each plot, depending on the tree species $(€ / t)$ Price $_{i}$, and the market discount rate $r$ (see Appendix E for all input details). Based on the literature (survey by Clark, 2001; Ding et al., 2016), we assumed that the timber selling price remains constant across the whole simulated period 2017-2100. We also justify this choice due to the very low impact of local shocks (supply or demand economic shocks resulting from the policy scenarios) on the timber marketplace.

\subsubsection{Sensitivity analysis for the economic valuation}

Economic forecasting analyses are characterized by a high level of uncertainty directly related to the selected level of discount rate applied to ES valuation. French legislation as well as many studies on land use planning projects recommend adopting a 4\% discount rate (Lebègue Report, 2005; Quinet Report, 2013; Trivino et al.,2015). Other studies tested the effect of various discount rates: from $1 \%$ to $8 \%$ in Bottalico et al. (2016) or from 1\% to $5 \%$ in Pukkala (2016). However, to account for the scarcity of natural resources and the strong and positive correlation between ecological growth and economic growth (Gosselin et al., 2011), the Stern Review and numerous studies recommend the use of a low discount rate of 1.5\% (Weitzman, 1998; Stern, 2006; Weitzman, 2007; Gollier, 2010; Freeman and Groom, 2013).

The selected discount rate can significantly modify the results. Therefore, we tested discount rates ranging from $1 \%$ to $4 \%$. However, in this work we only compare the effect of the scenarios on the ES values based on the reference year, 2017. Thus, even if the results are modified in level, they are not modified in relative terms. We finally selected a discount rate of $1.5 \%$, as recommended by the specific literature on economic valuation of biodiversity and ecosystems services (Stern, 2006; Gollier, 2010).

\section{Results}

To disentangle the effects of LULCC and forest adaptation policies on the socio-ecosystem evolution in various CC contexts, we present the results in three steps: (i) without LULCC and forest policy scenarios, i.e., the baseline; (ii) with LULCC but no adaptation policy, i.e., the BAU scenario; and (iii) with LULCC and adaptation policies, i.e., the BIO and WE scenarios (see Appendix C, Fig.C2). The analysis of the results was therefore conducted within time horizons, and between the different scenarios (CC, LULCC and adaptation) in 2050 and then in 2100. Carbon sequestration $\left(\mathrm{t}_{\mathrm{c}} \cdot \mathrm{ha}^{-1}\right)$ and timber production $\left(\mathrm{m}^{3}\right.$.ha $\left.{ }^{1}\right)$ in 2017 were computed from the past period, 1960-2017.

\subsection{Baseline: climate change results}

We defined the baseline changes as the $\mathrm{CC}$ effect alone under the climate scenarios used in the biophysical model. Figure 3 and Appendix I show the results in terms of biophysics and NPV for the climate change without LULCC and forest policy adaptation (BAU, BIO, and WE).

Figure 3 presents the results of carbon sequestration and timber production for the two main species in terms of surface area in Mont Ventoux: Pinus halepensis and Quercus pubescens. We observed a weak effect of climate scenario on ES until 2050 but a slightly more noteworthy effect for the timber production starting in 2080 and the carbon sequestration of Quercus pubescens starting in 2050. Indeed, for this last species from 2050, the carbon sequestration related to RCP8.5 is approximately 5\% 
higher than the carbon sequestration with RCP4.5. This is not the case for Pinus halepensis. Moreover, from 2080 , the timber harvested is $5 \%$ to $10 \%$ higher with climate scenario 8.5 . This is due to the fertilization effect of the $\mathrm{CO}_{2}$ increase on photosynthesis and water use efficiency and to the higher increase in growing season under the 8.5 scenario. These effects counterbalance the higher mortality under the 8.5 scenario.

Assessing the mortality risk allows for more precisely including the effect of climate change on the future of species and therefore on the production of ES. Indeed, its variation is explained at $70-90 \%$ by climate scenarios and thus marginally explained by the LULCC and adaptation scenarios. More specifically, mortality on Mont Ventoux is on average 2\% for RCP 4.5 and 4\% for RCP 8.5 in 2050 and then $3 \%$ for RCP 4.5 and $5 \%$ for RCP 8.5 in 2100 .

At the species level (Fig. 3 and Appendix I), the average difference between both RCPs is $-/+15 \%$ for carbon sequestration and $-/+5 \%$ for timber production. At the landscape level (Appendix J), the TNPV increases by $15 \%$ in 2050 from RCP4.5 to RCP8.5 and decreases by $15 \%$ in 2100 . Finally, few effects of CC scenarios (RCP4.5 and RCP8.5) were found on ES production and their related TNPV both at the species and landscape levels.

\subsection{Land cover changes}

LULCC evolution differs according to CC and policy scenarios. Indeed, even if the signs of trends for all species remain stable across our scenarios, they strongly differ in terms of magnitude. For instance, the Pinus nigra surface increases from $22 \%$ to $134 \%$ according to the studied scenarios (Fig. 4).

Using the stakeholder transition matrices, we projected that the area covered by Quercus pubescens and the Pinus sylvestris will strongly decrease due to climate change. According to forest managers, these two species will not adapt to CC in their current location in the future; they cannot move to a higher altitude level, and the managers have already observed a strong drought-related mortality rate. For Quercus ilex, Pinus halepensis, and Pinus nigra, forest managers anticipated different dynamics in the Ventoux. Due to the resilience of these species regarding CC, the area covered by these species is expected to increase because they will replace Quercus pubescens and Pinus sylvestris in different locations. Moreover, a policy scenarios effect occurs; Quercus ilex and Pinus nigra are the two species most favored by alternative forest policy scenarios: the BIO scenario supports Pinus nigra and Pinus halepensis development, and the WE scenario supports Quercus ilex and Pinus nigra.

\subsection{Socio-ecosystem evolution with land cover changes and adaptation strategies}

In this section, we present the ES variations, first including LULCC only (i.e., BAU scenario) and then including LULCC and adaptation strategies (i.e., BIO and WE scenarios). This allows us to observe the isolated and cumulative effects of the different drivers of change.

Figure 5 (and Appendix J) summarizes the changes in ES economic values according to these different factors. LULCC and adaptation positively affect the aggregated total value of ES in 2050 and 2100, increasing the TNPV by $30 \%$ to $120 \%, 50 \%$ on average, compared with the baseline. Moreover, in three cases, RCP4.5 and RCP8.5 in 2100 and RCP4.5 in 2050, the best scenario in terms of ecosystem services production aimed at promoting biomass; in the fourth case, RCP8.5 in 2050, the best scenario targeted the production of wood energy (see Fig. 5). The role of adaptation strategies on ES changes is highly variable according to the time horizon and the ES considered. The effects of LULCC are significant but opposite for the two ES (Appendix J). LULCC and the new species distribution at the landscape scale 
(see part 3.2) appear favorable for carbon sequestration but detrimental to timber production. The first effect is partly explained by the increase in Pinus halepensis and Pinus uncinata, and the second effect is partly explained by the decrease in Quercus pubescens. The effects of adaptation strategies, in addition to the LULCC, are significant and highly positive for the aggregated value of ES. However, each adaptation strategy affects ES differently. The biomass scenario is positive for carbon sequestration and negative for timber production, and the promotion of wood energy is positive for both ES but strongly favors timber production. As a result, the results vary according to the ES and the time horizons. The overall results are in line with the literature (Bottalico et al. 2016; Chiabai et al. 2011; Ding et al., 2016; Morán-Ordóñez et al., 2020).

Finally, combined with LULCC and adaptation strategies, a climate scenario effect on the ES results exists. Figure 5 shows higher TNPV for RCP8.5 than for RCP4.5 for both horizons, 2050 and 2100. Indeed, comparing the TNPV in the case of LULCC and adaptation strategies with the baseline, we can observe that positive effects in RCP 8.5 are almost twice those in RCP 4.5.

All of these results assume a contrasting effect of the scenarios on the two ecosystem services, which is confirmed by Pearson's correlation analysis (see Appendix K). In the case of the spatial correlation analysis of the BAU, the correlation between the two ES is positive (around 0.7) in 2050 and then negative in 2100 (around -0.1). For adaptation scenarios (BIO and WE), the spatial correlations between ES vary more strongly for the WE in 2100 , with correlations decreasing from 0.9 to 0.5 , but the correlations remain stable for the BIO scenario.

\section{Discussion}

In this paper, we developed a socioeconomic and ecological methodology co-constructed with stakeholders to explore the effect of different scenarios of forest policies and CC on future ES provision (carbon sequestration and timber production) in a spatially sensitive and dynamic way, combining biophysical and economic values. This methodology, organized around the co-construction of change scenarios and transition matrices according to the stakeholders' local expertise, allows for the replicability of the study (as structured by the Wayfinder guideline ${ }^{2}$ ).

Our contribution is threefold. First, our predictions of the effect of CC scenarios on ES evolution are rather optimistic. Indeed, process-based predictions rely on physiological mechanisms to predict future ecosystem functioning, which corresponds to the fundamental niche of the species (Keenan et al., 2011). By contrast, predictions based on correlative species distribution models are usually more pessimistic because they derive their predictions from the realized bioclimatic niche of the species, which can be much more restricted than the fundamental niche for some species. Second, LULCC has the effect of increasing the changes and accentuating the difference between climate change scenarios. This result combines two effects: (1) a more pessimistic prediction by managers (probably the result of previous works based on correlative models and more pessimistic conclusions - particularly maps which have left their mark on foresters' management) and, as a consequence of this first point, (2) an anticipation action that tends to overanticipate and reinforce or even accelerate the expected changes. In this sense, the impact of adaptive actions, influenced by some models' predictions, can become

\footnotetext{
2 " Wayfinder represents a new generation of resilience practice that will guide development practitioners, policymakers and other change-makers navigating towards better futures. » https://graid.earth/projects/wayfinder/
} 
greater than the impact of climate change itself. The action in adaptive strategy must be flexible and regularly reviewed according to the improvement of knowledge and scenario predictions. Third, even if the impact of economic choices is not major in our case study (we focus on a long-term management region rather than on short-term intensive management), our work shows that large-scale political orientations (i.e., adaptation strategies) impact ES. For the ES relationship, without adaptation scenarios, we can make wrong conclusions about synergy or conflict. Moreover, unlike the BIO scenario, which strengthens the synergies between ES, the WE scenario appears to weaken them considerably. In line with several previous case studies, LULCC and adaptation strategies appear to be decisive drivers of the future ES evolution (Morán-Ordóñez et al., 2020; Bréteau et al., 2019).

A few limitations and refinements of the study must be discussed to provide better modeling and policy orientations. First, rigorously comparing model and stakeholder results is difficult because simulation and forest management account for distinct elements. For example, managers not only anticipate the effect of CC on carbon sequestration but also the timber production and the future of the sectors. However, we can compare their global trends (upward/downward), and we can analyze what they are related to. Second, the NPV of carbon sequestration and the NPV of timber production (see Appendix J) differ by a hundred-fold. However, the "factor effect" is greatly attenuated in our analysis as we look at the results in terms of variations for each ES and then for the TNPV. Finally, regarding the use of process-based models, work still needs to be conducted in several directions. We may underestimate the tipping points in terms of hydraulic failure or the effects of multiple disturbances (drought, insects, and fire). In Davi et al. (2006), we showed that the main positive effect of climate change on the photosynthesis of evergreen species was due to the increase in atmospheric $\mathrm{CO}_{2}$, whereas the increase in vegetation duration mainly has an effect on deciduous species. We therefore looked at the relationship between GPP and $\mathrm{CO}_{2}$ simulated for pines by CASTANEA in this study and compared this relationship with the measurements obtained in the FACE experiments on a Pinus ponderosa forest at a Duke site (Appendix G). CASTANEA reproduces the increasing water use efficiency (WUE) well for pine trees but underestimates the GPP fertilization (+23\% instead of $30 \%$ at the Duke forest). However, we may still overestimate the fertilizing effect of $\mathrm{CO}_{2}$ by the absence of acclimatization of photosynthesis to $\mathrm{CO}_{2}$ and feedback of the nitrogen cycle. Moreover, huge uncertainties exist regarding soil organic carbon simulations (Smith et al., 2020), but CASTANEA reproduces the ranges of soil carbon stock and soil respiration, the relative variations between species and the effect of altitude well (Appendix $\mathrm{H}$ ).

\section{Conclusion}

We conclude with directions that can be taken in future research. First, this work is valid for the public forest sector and management, but it does not include specific private forest silviculture. One obvious difference between private and public forests, which tends to disappear over time, is relying on the ES integration in forest management: if ES are normally integrated in public forest management, some incentives need to be implemented for private owners as these goods are public goods for most of them. Another possible extension addresses how some local impacts on demand or supply sides can diffuse at a more global scale. 


\section{Acknowledgements}

This work was supported by a grant from the ERA-NET FORESTERRA project INFORMED. The authors wish to thank the following for their cooperation and constructive discussions regarding the issues raised in this paper: Olivier Delaprison, Jean Ladier, Anthony Roux, Philippe Dreyfus, the different members of the INFORMED workshop, and reviewers/participants at the Ecosystem Services Partnership (ESP) Regional Europe conference (San Sebastian, 2018) for their useful comments.

\section{References}

Adams, H.D., Zeppel, M.J.B., Anderegg, W.R.L., Hartmann, H., Landhäusser, S.M., et al. (2017). A multispecies synthesis of physiological mechanisms in drought-induced tree mortality. Nature Ecology \& Evolution 1, 1285-1291. https://doi.org/10.1038/s41559-017-0248-x

Barbero M., Quézel P. (1976). La déprise rurale et ses effets sur les superficies forestières dans la région ... Thèse, Université Marseille-Saint Jérôme, Oxford.

Berg C., Rogers S., Mineau M. (2016). Building scenarios for ecosystem services tools: Developing a methodology for efficient engagement with expert stakeholders, Futures, 81, pp68-80. https://doi.org/10.1016/j.futures.2015.10.014

Bottalico F., Pesola L., Vizzarri M., Antonello L., Barbati A., et al. (2016). Modeling the influence of alternative forest management scenarios on wood production and carbon storage: A case study in the Mediterranean region, Environ Res., pp14472-87. https://doi.org/10.1016/j.envres.2015.10.025

Brodribb, T.J., Cochard, H., 2009. Hydraulic Failure Defines the Recovery and Point of Death in WaterStressed Conifers. Plant Physiol. 149, 575-584. https://doi.org/10.1104/pp.108.129783

Brèteau-Amores S., Brunette M., Davi H., An Economic Comparison of Adaptation Strategies Towards a Drought-induced Risk of Forest Decline, Ecological Economics, Vol. 164, 2019. https://doi.org/10.1016/j.ecolecon.2019.04.006.

Chiabai A., Travisi C.M., Markandya A., Ding H., Nunes P. (2011) Economic Assessment of Forest Ecosystem Services Losses: Cost of Policy Inaction, Environ Resource Econ 50: 405-445.

Choe H., Thorne J.H. (2017). Integrating Climate Change and Land Use Impacts to Explore Forest Conservation Policy. Forests, 8, 321. https://doi.org/10.3390/f8090321

Clark, J. (2001). The global wood market, Prices and plantation investment: an examination drawing on the Australian experience, Environ. Conserv., 28 (1), pp53-64. https://doi.org/10.1017/S0376892901000054

Costanza R., Kubiszewski I., Ervin D., Bluffstone R., Boyd J., et al. (2011). Valuing ecological systems and services. F1000. Biol. Rep., 3:14. https://doi.org/10.3410/B3-14

Croitoru L. (2007). Valuing the non-timber forest products in the Mediterranean, Ecol. Econ., vol3: 4, pp768-775. https://doi.org/10.1016/j.ecolecon.2007.01.014

Davi H., Dufrêne E., Granier A., Le Dantec V., Barbaroux C., François C., Bréda, N. (2005). Modelling carbon and water cycles in a beech forest: Part II.: Validation of the main processes from organ to stand scale. Ecological Modelling, 185, pp387-405. Doi.org/10.1016/j.ecolmodel.2005.01.003

Davi, H., Dufrêne, E., Francois, C., Le Maire, G., Loustau, D., Bosc, A., Rambal, S., Granier, A., Moors, E., 2006. Sensitivity of water and carbon fluxes to climate changes from 1960 to 2100 in European forest ecosystems. Agricultural and Forest Meteorology 141, 35-56. https://doi.org/10.1016/j.agrformet.2006.09.003

Davi H., Cailleret M. (2017). Assessing drought-driven tree mortality with a process-based model. Agricultural and Forest Meteorology, 232, pp279-290. https://doi.org/10.1016/j.agrformet.2016.08.019 
de Cáceres, M., Martínez-Vilalta, J., Coll, L., Llorens, P., Casals, P., Poyatos, R., Brotons, L., 2015. Coupling a water balance model with forest inventory data to predict drought stress: the role of forest structural changes vs. climate changes. Agric. For. Meteorol. 213, 77-90.

De Groot R.S., Kumar P., van der Ploeg S., Sukhdev P. (2010). Estimates of monetary values of ecosystem services, P. Kumar (Ed.), TEEB Foundations, The Economics of Ecosystems and Biodiversity: Ecological and Economic Foundations (Eds.), Earthscan, London (2010).

Ding H., Chiabai A., Silvestri S., Nunes P. (2016). Valuing climate change impact on European forest ecosystem, Ecosystem Services, 18, pp141-153. https://doi.org/10.1016/j.ecoser.2016.02.039

Dufrêne E., Davi H., Francois C., le Maire G., Le Dantec V., \& Granier A. (2005). Modelling carbon and water cycles in a beech forest Part I: Model description and uncertainty analysis on modelled NEE. Ecological Modelling, 185, pp407-436. https://doi.org/10.1016/j.ecolmodel.2005.01.004

Durand Y., Giraud G., Brun E., Mérindol L., Martin E. (1999). A computer-based system simulating snowpack structures as a tool for regional avalanche forecasting. J. Glaciol., 45, pp 469-484. https://doi.org/10.3189/S0022143000001337

FAO (2011). The European Forest Sector Outlook Study II (EFSOS II), 2010-2030, UNECE/FAO Study Paper No. 28.

FAO (2014). A new dynamic for Mediterranean forests. Rome, Italy. Issue 1, vol 65. 84pp.

Fontes, Luis et al. Models for supporting forest management in a changing environment. Forest Systems, [S.I.], v. 19, p. 8-29, oct. 2010. ISSN 2171-9845. doi:http://dx.doi.org/10.5424/fs/201019S9315.

Freeman M.C., and Groom B. (2013). Biodiversity valuation and the discount rate problem, Accounting, Auditing\& Accountability Journal, Vol. 26 No. 5, pp. 715-745.

García-Nieto A.P., García -Lorrente M., Iniesta-Arandia I., Martín-López B. (2013). Mapping forest ecosystem services: From providing units to beneficiaries, Ecosystem Services, 4, pp126-138. https://doi.org/10.1016/j.ecoser.2013.03.003

Gollier C. (2010). Ecological discounting, Journal of Economic Theory, 145, pp812-829. https://doi.org/10.1016/j.jet.2009.10.001

Gosselin M., Costa S., Paillet Y., Chevallier H. (2011). Actualisation en forêt : pour quelles raisons et à quel taux ? Revue forestière française, vol. 63 : 4, pp445-455. https://doi.org/10.4267/2042/45828

Guillemot, J., Francois, C., Hmimina, G., Dufrêne, E., Martin-StPaul, N.K., Soudani, K., Marie, G.,

Ourcival, J.-M., Delpierre, N., 2016. Environmental control of carbon allocation matters for modelling

forest growth. New Phytol n/a-n/a. https://doi.org/10.1111/nph.14320

Harmáčková Z.V., Vačkář D. (2018). Future uncertainty in scenarios of ecosystem services provision: Linking differences among narratives and outcomes, Ecosystem Services, 33, pp134-145. https://doi.org/10.1016/j.ecoser.2018.06.005.

Hoogstra-Klein, M. A., \& Burger, M. (2013). Rational versus adaptive forest management planning: Exploratory research on the strategic planning practices of Dutch forest management organizations. European Journal of Forest Research, 132(5-6), 707-716. https://doi.org/10.1007/s10342-0130707-0

Hubert C., Magrum M., Peloss H., Ravon-Berenguer M.A. (2015). Le régime forestier mis en œuvre par l'office national des forêts dans les forêts des collectivités, CGAAER - CGDD-IGF report.

Kareiva, P., Tallis, H., Ricketts, T. H., Daily, G. C., \& Polasky, S. (2011). Natural capital: theory and practice of mapping ecosystem services. Oxford: University Press.

Keenan T., Serra J.M., Lloret F., et al. (2011). Predicting the future of forests in the Mediterranean under climate change, with niche- and process-based models: CO2 matters! Global Change Biology (2011) 17, 565-579, doi: 10.1111/j.1365-2486.2010.02254.x

Kubiszewski I., Costanza R., Anderson S., Sutton P. (2017). The future value of ecosystem services: Global scenarios and national implications, Ecosystem Services, 26, pp289-301. https://doi.org/10.1016/j.ecoser.2017.05.004.

Ladier J., Rey F., Dreyfus Ph. (2012) Guide des Sylvicultures de Montagne Alpes du Sud françaises. 
Lamarque P., Lavorel S., Mouchet M., Quétier F. (2014). Plant trait-based models identify direct and indirect effects of climate change on bundles of grassland ecosystem services, PNAS, 111 (38), pp13751-13756. https://doi.org/10.1073/pnas.1216051111

Lebègue D., Baumsstark L., Hirztman P. (2005) Révision du taux d'actualisation des investissements publics, La Documentation Française, Paris.

Lidskog, R., \& Löfmarck, E. (2015). Managing uncertainty: Forest professionals' claim and epistemic authority in the face of societal and climate change. Risk Management, 17(3), 145-164. https://doi.org/10.1057/rm.2015.10

Lidskog, R., \& Löfmarck, E. (2016). Fostering a flexible forest: Challenges and strategies in the advisory practice of a deregulated forest management system. Forest Policy and Economics, 62, 177-183. https://doi.org/10.1016/i.forpol.2015.10.015

Lopez-Garcia (2018). Assessing ecosystem functioning on Mediterranean forests in the context of global change: the case study of Mont Ventoux. Erasmus Mundus International Master program MEDfOR. Master thesis.

Martinez-Harms M-J., Bryan B.A., Figueroa E., Pliscoff P., Runting R.K., Wilson K.A. (2017). Scenarios for land use and ecosystem services under global change, Ecosystem Services, 25, pp56-68. https://doi.org/10.1016/j.ecoser.2017.03.021.

Martinez de Araño I, Muys B, Corrado T, Pettenella D, Feliciano D, et al. (2018). A forest-based circular bioeconomy for southern Europe: visions, opportunities and challenges. Reflections on the bioeconomy. European Forest Institute (EFI), Joennssu, Finland, 117p.

Masiero, M., Pettenella, D.M., Secco, L. (2016). From failure to value: economic valuation for a selected set of products and services from Mediterranean forests, Forest Systems, 25:1, e051. https://doi.org/10.5424/fs/ 2016251-08160

McKenzie, E., Rosenthal, A., Bernhardt, J., Girvetz, E., Kovacs, K., Olwero, N., et al. (2012). Developing Scenarios to Assess Ecosystem Service Tradeoffs: Guidance and Case Studies for InVEST Users.

McSweeney C.F., Jones R.G., Lee R.W. et al. (2015). Selecting CMIP5 GCMs for downscaling over multiple regions, Climate Dynamics, 44, p3237. https://doi.org/10.1007/s00382-014-2418-8

Morán-Ordóñez, A., Roces-Díaz, J.V., Otsu, K. Ameztegui, A., Coll, L., Lefèvre, F., Retana, J., Brotons, L. (2018). The use of scenarios and models to evaluate the future of nature values and ecosystem services in Mediterranean forests, Reg. Environ. Change, 19:2, pp415-428. https://doi.org/10.1007/s10113-018-1408-5

Morán-Ordóñez A, Ameztegui A., De Cáceres M., de-Miguel S., Lefèvre F., Brotons L., Coll L. (2020). Future trade-offs and synergies among ecosystem services in Mediterranean forests under global change scenarios, Ecosystem Services, Volume 45, https://doi.org/10.1016/j.ecoser.2020.101174.

Moss R. H., Edmonds, J.A., Hibbard, K. A., Manning, M.R., Rose, S.K., van Vuuren, D.P., Carter, T.R., Emori, S., Kainuma, M., Kram, T., et al. (2010). The next generation of scenarios for climate change research and assessment, Nature, 463: 747. https://doi.org/10.1038/nature08823

Oddou-Muratorio S., Davi H. (2014). Simulating local adaptation to climate of forest trees with a Physio-Demo-Genetics model, Evolutionary Applications, 7, pp 453-467. https://doi.org/10.1111/eva.12143

Oddou-Muratorio, S., Davi, H., Lefèvre, F., 2020. Integrating evolutionary, demographic and ecophysiological processes to predict the adaptive dynamics of forest tree populations under global change. Tree Genetics \& Genomes 16, 67. https://doi.org/10.1007/s11295-020-01451-1

Pukkala T. (2016). Which type of forest management provides most ES, Forest Ecosystems, vol. 3:9, $16 \mathrm{p}$.

Quinet E., Baumstark L., Bonnet J., Croq A., Ducos G., Meunier D., Rigard-Cerison A., Roquigny Q. (2013) L'évaluation socioéconomique des investissements publics, Commissariat Général à la Stratégie et à la Prospectives, La documentation Française, Paris.

Schirpke U., Kohler M., Leitinger G., Fontana V., Tasser E., Tappeiner U. (2017). Future impacts of changing land-use and climate on ecosystem services of mountain grassland and their resilience, Ecosystem Services, 26, Part A, pp79-94. https://doi.org/10.1016/j.ecoser.2017.06.008. 
Small N., Munday M., Durance I. (2017). The challenge of valuing ecosystem services that have no material benefits, Global Environmental Change, 44, pp57-67. https://doi.org/10.1016/j.gloenvcha.2017.03.005

Stern N. (dir.) (2006). The Stern Review Report: The Economics of Climate Change. London, HMTreasury, $603 \mathrm{p}$.

Tallis H.T., Polasky S., (2009). Mapping and Valuing Ecosystem Services as an Approach for Conservation and Natural-Resource Management, Annals of the New York Academy of Sciences, 1162(1), pp265-83. https://doi.org/10.1111/j.1749-6632.2009.04152.x

Tallis H.T., Ricketts T., Guerry A.D., Wood S.A., Sharp R., Nelson E., et al. (2013) InVEST 2.6.0 User's Guide, The Natural Capital Project, Stanford University, Stanford.

Tardieu, L. (2017). The need for integrated spatial assessments in ecosystem service mapping. Review of Agricultural, Food and Environmental Studies, 98, pp173-200. https://doi.org/10.1007/s41130017-0054-5.

Triviño M., Juutinen A., Mazziotta A., Miettinen K., Podkopaev D., Reunanen P., Mönkkönen M. (2015). Managing a boreal forest landscape for providing timber, storing and sequestering carbon, Ecosystem Services, 14, pp179-189.

Urli, M., Porté, A.J., Cochard, H., Guengant, Y., Burlett, R., Delzon, S (2013). Xylem embolism threshold for catastrophic hydraulic failure in angiosperm trees. Tree Physiol 33, 672-683. https://doi.org/10.1093/treephys/tpt030

van Vuuren, D.P., Edmonds J., Kainuma M. et al. (2011). The Representative Concentration Pathways: An Overview, Climatic Change, 109 (1-2), pp5-31. https://doi.org/10.1007/s10584-011-0148-z

von Detten, R. (2011). Sustainability as a guideline for strategic planning? The problem of long-term forest management in the face of uncertainty. European Journal of Forest Research, 130(3), 451465. https://doi.org/10.1007/s10342-010-0433-9

Watkiss P. (2006). The Social Cost of Carbon, OECD report, 9p.

Weitzman M.L. (1998), "Why the far-distant future should be discounted at its lowest possible rate", Journal of Environmental Economics and Management, Vol. 36 No. 3, pp. 201-208.

Weitzman M.L. (2007), "A review of the Stern Review on the economics of climate change", Journal of Economic Literature, Vol. 45 No. 3, pp. 703-724. 


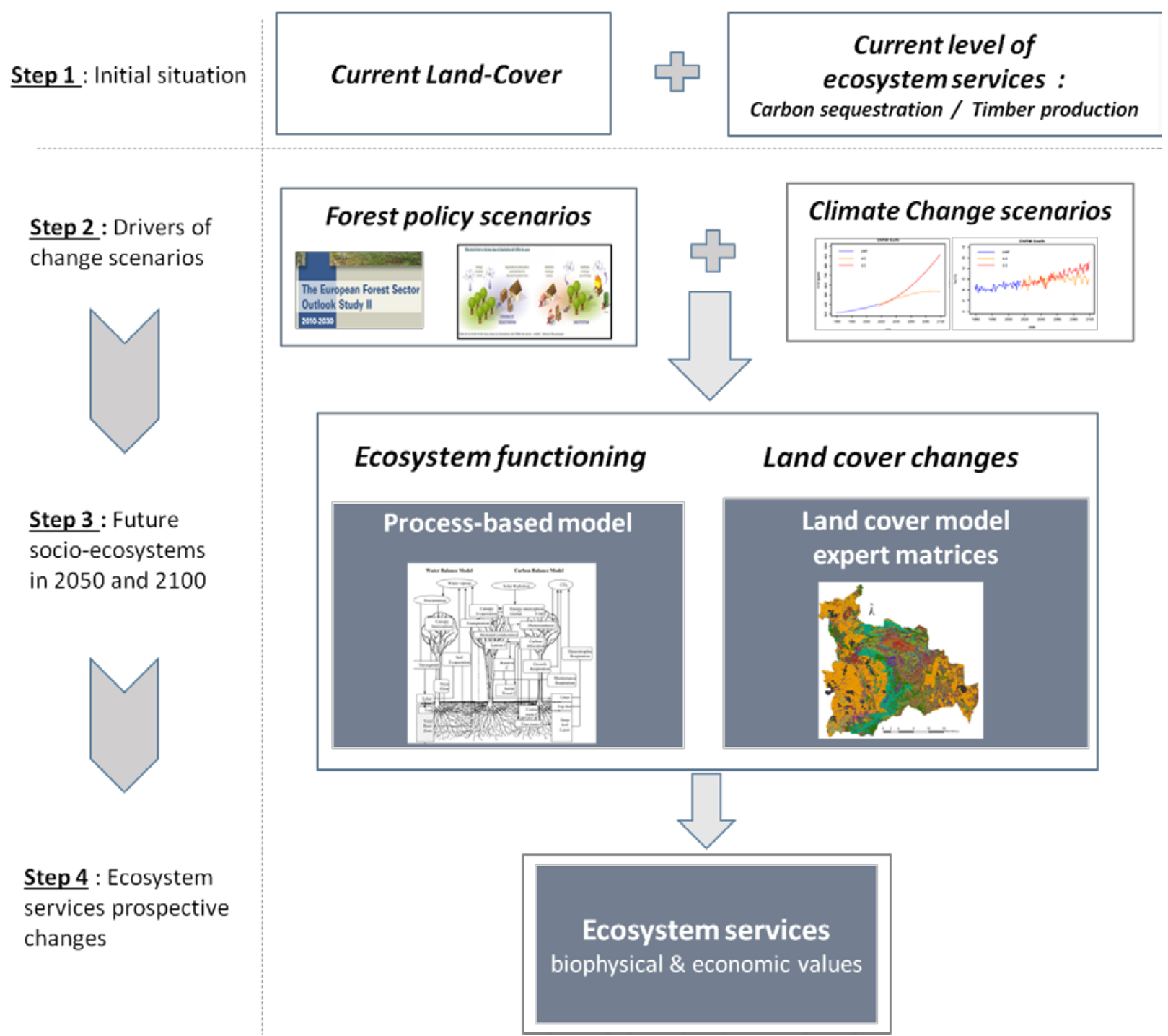

Fig.1. Snapshot of the methodology in four steps. 


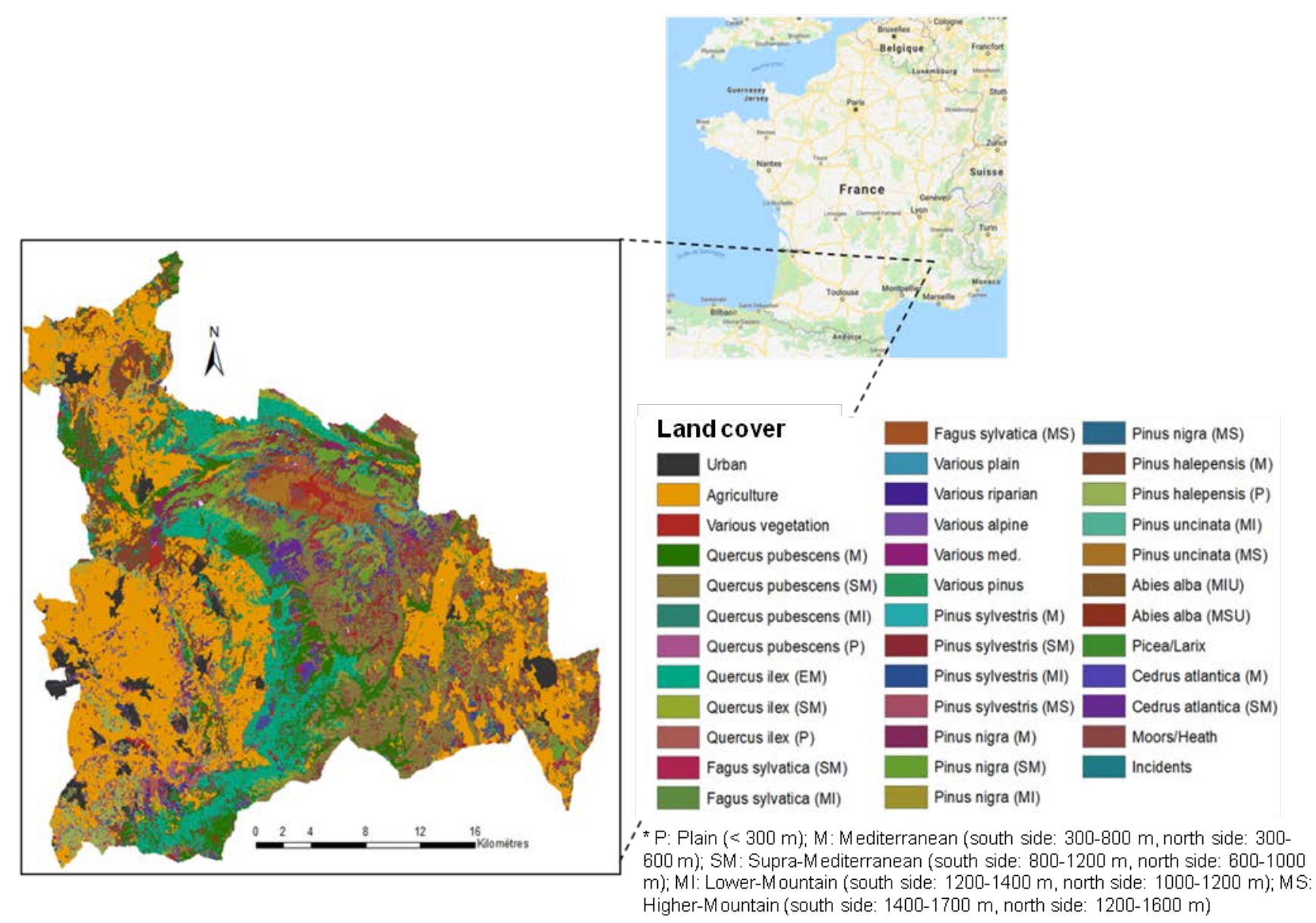

Fig. 2. The Mont-Ventoux study site and its land cover typology. 

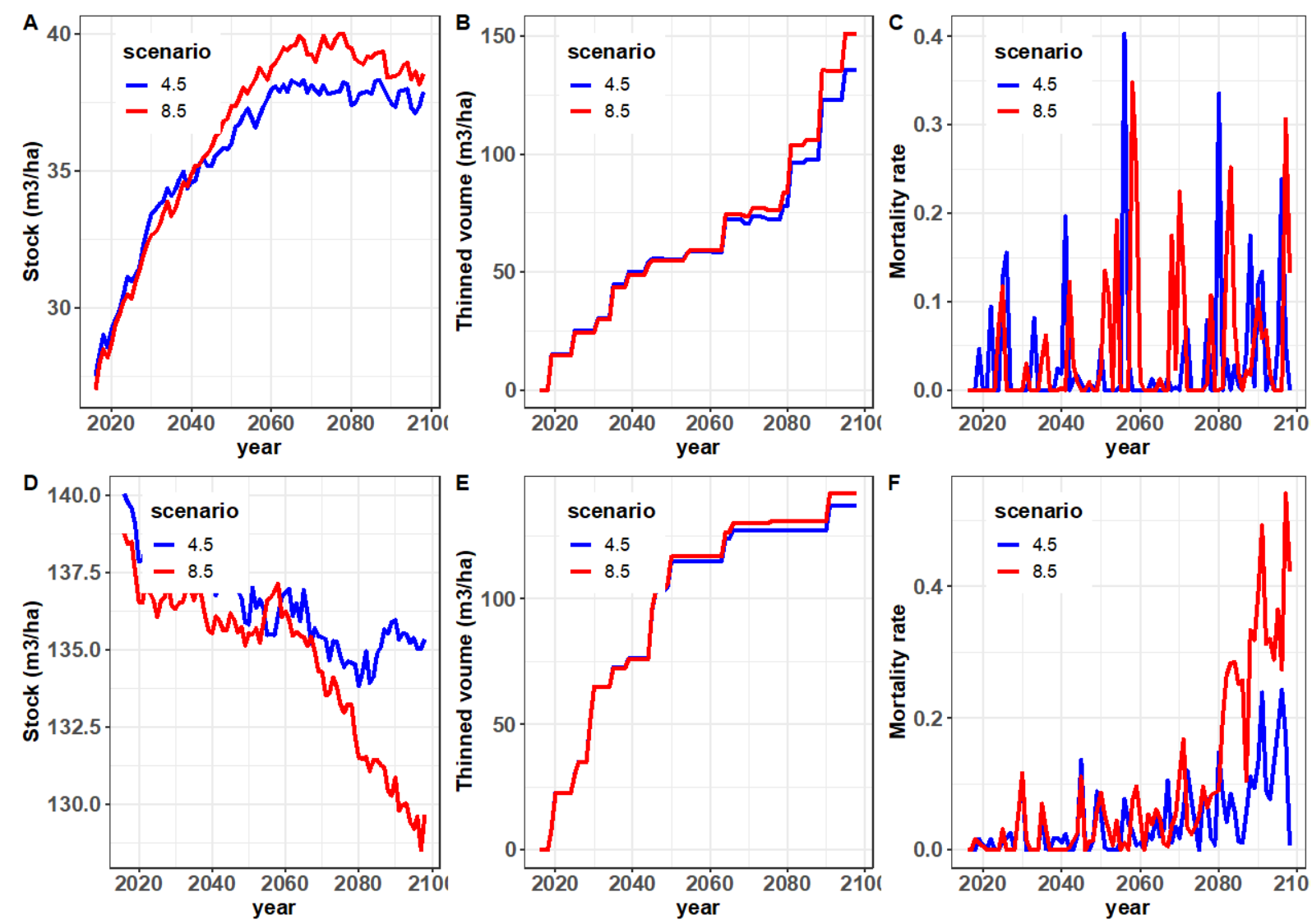

Fig. 3. Carbon stock $\left(\mathrm{t}_{\mathrm{c}} \cdot \mathrm{ha}^{-1}\right)$, timber production $\left(\mathrm{m}^{3} \cdot \mathrm{ha}^{-1}\right)$ and mortality (in \%) predictions in the 20172100 period under two climate scenarios (RCP4.5 and RCP8.5): the example of Quercus pubescens (A, $B, C)$ and Pinus halepensis (D, E, F). 


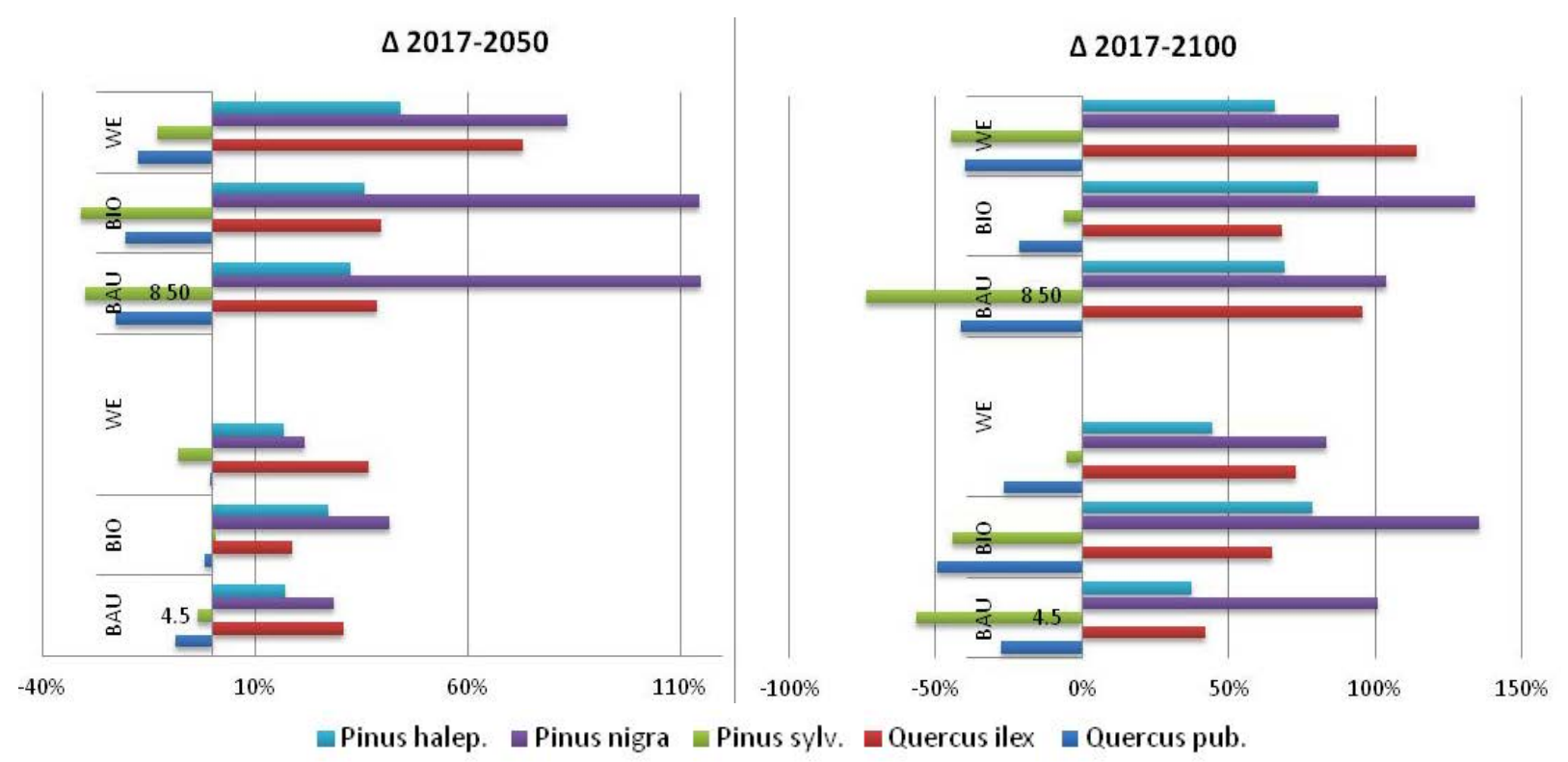

Fig. 4. Land cover variations (in \%) between 2017 and the two time horizons, 2050 (left side) and 2100 (right side) and scenarios (business as usual (BAU), biomass (BIO), wood energy (WE)), according to the expertise of the stakeholder panel for the five main tree species: Pinus halepensis, Pinus nigra, Pinus sylvestris, Quercus ilex, and Quercus pubescens. 


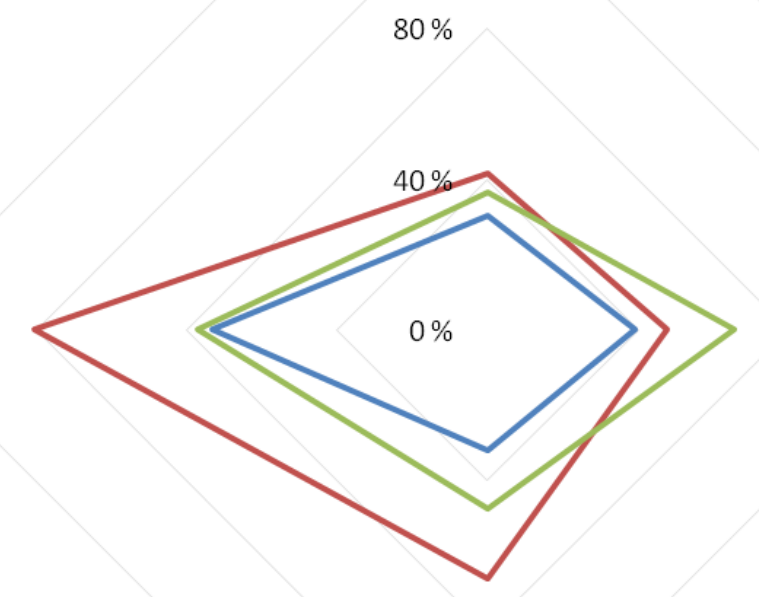

Fig. 5. Evolutions (rate of change in \%) of the total net present value (sum of the carbon and timber economic values in euros) between the scenarios (business as usual (BAU), biomass (BIO), wood-energy (WE)) and the baseline for two Representative Concentration Pathways, 4.5 and 8.5, and two time horizons, 2050 and 2100. 
Table. 1. Forestry planning (age and percentage harvested) according to three scenarios: business as usual (BAU), biomass (BIO), wood energy (WE).

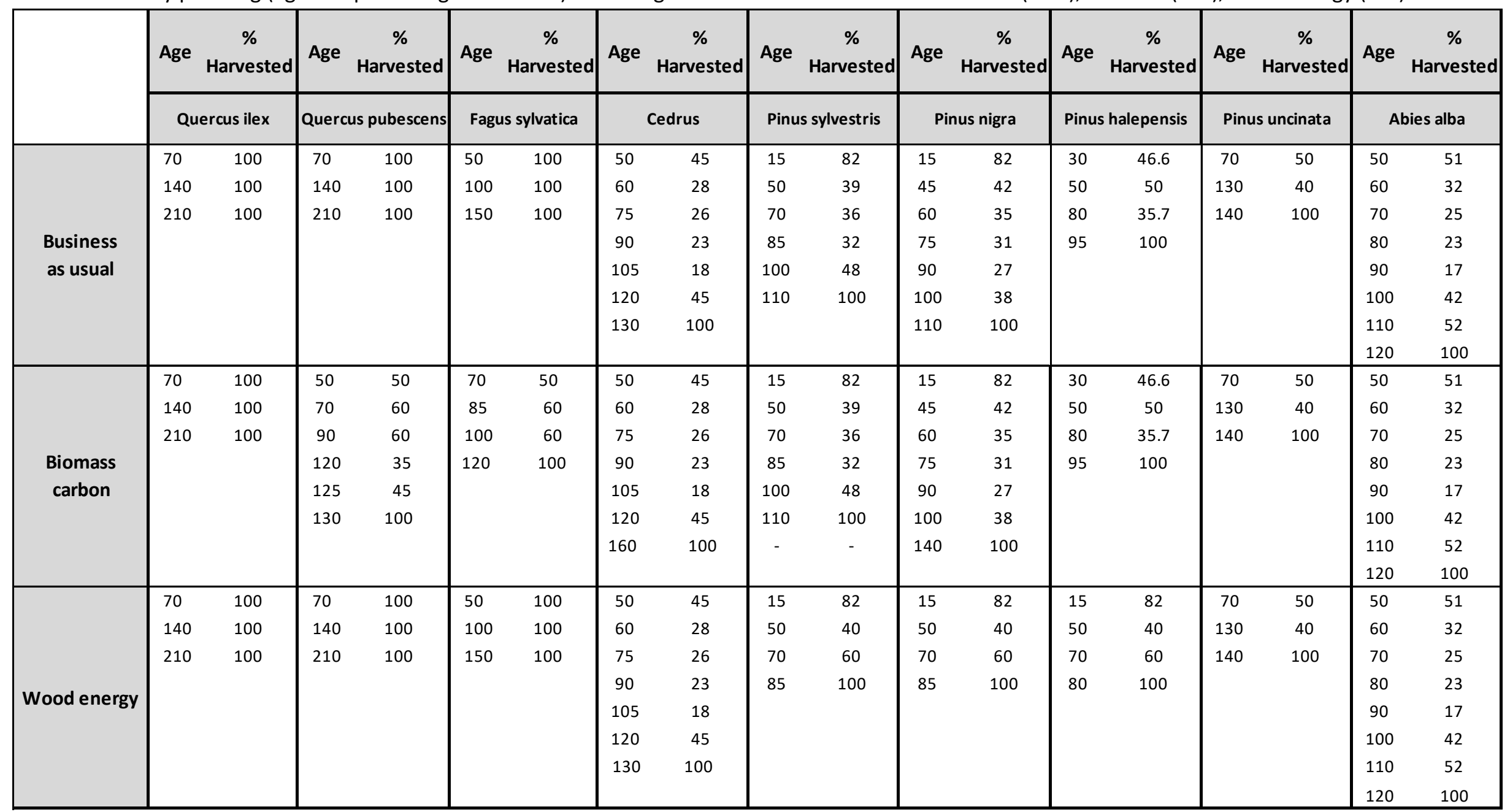

